\title{
László Borbála
}

\section{Túlélöhalottak: A poszttraumás állapot, a gyász és a gyógyulás fenomenológiája az Akik maradtak (2019) címú filmben}

\begin{abstract}
Absztrakt
Tóth Barnabás 2019-ben megjelent, Akik maradtak címú filmjében a traumatizáció úgy jelenik meg, hogy a fôsszereplôk beletörődnek pszichéjük idegenségébe, és helyette a test életben tartására koncentrálnak: habár túlélték a Holokausztot, élôhalottként tekinthetünk rájuk. Pintér Judit trauma-elméletére támaszkodva a tanulmány amellett érvel, hogy a két karakter egyszerre zárkózik el környezetétôl és saját magától, hiszen a trauma egy feldolgozhatatlan élményként behatol az énjükbe és megmérgezi azt. Főhôseink idegenként „élnek” saját testükben. A tanulmány által vizsgált fố kérdés az, hogy a film szerint el lehet-e beszélni az elbeszélhetetlent és feldolgozni a soha nem múló traumát, mely ezt az állapotot okozza. A szerzó azt állítja, hogy az Akik maradtak húen tanúskodik a trauma soha nem múló jellegérôl, illetve annak elbeszélhetetlenségérôl, azonban mindemellett optimista a gyászmunka kapcsán. A szereplók pillantások, érintések és multiszenzoriális emlékképek segítségével „beszélnek” traumáikról; beszéd helyett a nonverbális kommunikáció, a taktilitás és egyéb, szenzoriálisan tapasztalt érzetek kapnak kulcsszerepet a gyászmunkájukban. A szereplôk élményeit, gyászukat és közös gyógyulásukat a filmnyelv ugyancsak, Laura U. Marks elnevezésével élve, haptikus módon ábrázolja.
\end{abstract}

\section{Szerzô}

László Borbála PhD hallgató a Debreceni Egyetem Irodalom- és Kultúratudományok Doktori Iskola angol irodalom- és kultúratudományi alprogramjában. Kutatási területe az animal studies, az emberi és nem-emberi állatok kapcsolatának kultúratudományi vizsgálata, mely irányzaton belül fôként a kutya-ember kapcsolat irodalmi, közönség- és múvészfilmes ábrázolásai foglalkoztatják. Érdeklődési körébe tartozik továbbá a film és fenomenológia; a The AnaChronisT 2019-es számában megjelent tanulmányában a filmes tekintet szerzói filmes megnyilvánulásait vizsgálta.

https://doi.org/10.31176/apertura.2021.16.4.3 


\section{László Borbála}

\section{Túlélóhalottak: A poszttraumás állapot, a gyász és a gyógyulás fenomenológiája az Akik maradtak (2019) címú filmben}

1948-ban járunk, a második világháború sebeiból gyógyuló Budapesten, fülünk még lüktet, cseng a robbanást követố csendben. Az elénk táruló kórházi folyosón úgy megyünk végig, mintha üvegburában lennénk. Az elôttünk haladó nôvér hátrafordul, látszólag mond valamit, de szavai, csakúgy, mint a hozzánk idegesen odalépô, leendô apukáé, kivehetetlenek. Tóth Barnabás Akik maradtak címú tévéfilmjének nyitójelenetét Körner Aladár (Hajduk Károly), szülész-nőgyógyász orvos szubjektív szemszögéből látjuk, egy olyan emberéből, aki habár túlélte a Holokausztot és visszatért munkahelyére, családjának halálát nem tudta feldolgozni. Testben jelen van, de emlékeit, érzelmeit elfojtva, érzéki tompultságban éli mindennapjait, amíg a tizenhat éves Klára (Szőke Abigél), ki ugyancsak elvesztette családtagjait, egy nap meg nem jelenik nála a rendelôben. A kettejük között kialakuló kapcsolat hatására a férfi kissé megnyílik, azonban a nyitójelenet tompultsága és szótlansága a film egészét uralja, amely ezáltal egyrészt húen tanúskodik a trauma soha nem múló jellegérôl, másrészt annak elbeszélhetetlenségéról.

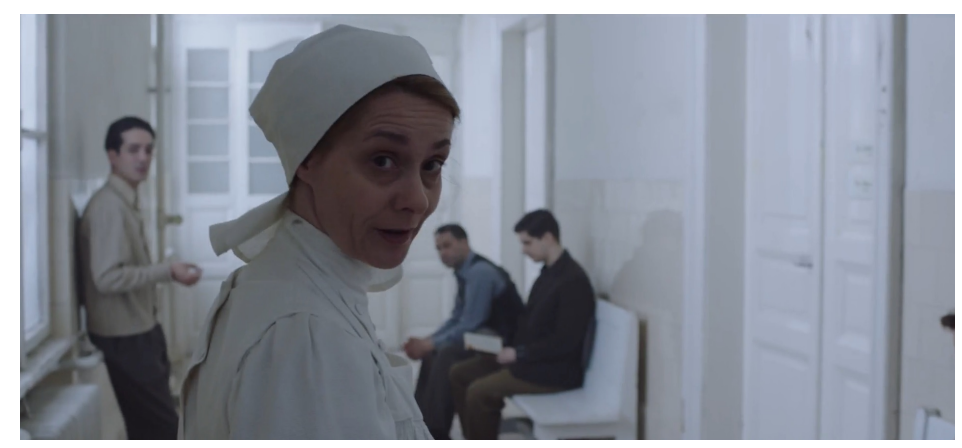

Akik maradtak (Tóth Barnabás, 2019)

A két fốszereplố még egymásnak [a közöttük kialakuló intim viszony ellenére [sem tud nyíltan beszélni mindarról, ami velük és szeretteikkel történt: a trauma bizonyos értelemben elnémította és megsüketítette ôket. Aladár, becenevén szólítva Aldó karaktere némaként ragadható meg, mivel nem képes szóban kifejezni érzelmeit. A dacos, utálkozó, kortársait és tanárait, valamint az ôt nevelô nagynénjét lenéző Klára pedig süketként értelmezhető, hiszen nem hajlandó „meghallani” a halált: makacsul tagadja szülei elvesztését, és továbbra is hosszú leveleket ír nekik. Egyúttal az élet hangjait is kizárja: nagynénje, Olgi (Nagy Mari) hiába kéri, hogy egyen rendesen, a lány erre azt válaszolja, hogy felhagyott az evéssel, ${ }^{[1]}$ nem hallgat a tanárai intéseire, hogy tanuljon, és a hozzá közeledô fiú, Pepe táncról, sportról, Amerikáról szóló lelkes monológjait is csak elengedi a 
füle mellett, mint gyermeteg, komolytalan meséket. Röviden, sem saját testére, sem másokra nem hallgat, hiszen mindezen belsô és külsô hangok arra emlékeztetik, hogy az élet szülei elvesztése ellenére is megy tovább. Habár igaz, hogy kettejük kapcsolatában Klára intenzívebben kimutatja érzelmeit, mint Aldó, személyes hangvételú csacsogásával, a férfinak szegezett kérdéseivel és környezete kritizálásával valójában ô is elfojt, terel, elkerüli a szülei halálával való szembenézést. Aldóhoz hasonlóan Klára is bezárkózik saját világába, de saját magán belül is létrehoz egy olyan zárt emléktárat, amelynek kinyitása túl fájdalmas lenne.

Mindkét karakter esetében egyszerre beszélhetünk a traumatizált egyén környezettôl való elzárkózásától, illetve a traumadiskurzusok által leírt énbeli hasadásról, a szubjektum saját magától való elidegenedésérôl. Ezt az állapotot jól példázza Klára beceneve, Süni, amit Aldó azért talált ki neki, mert a lány nemcsak kifelé, de befelé is tüskéket növeszt, másokkal és önmagával egyaránt ellenséges. Pintér Judit úgy fogalmaz, hogy „a trauma elidegenít önmagamtól” (2014: 7), amennyiben „az »önmagammal való közösségbe " olyan idegenszerúséget juttat, amely megkérdôjelezi önazonosságom mibenlétét” (2014: 31). Ilyen értelmezésben tehát a trauma két folyamatot is magába foglal: egyrészt valami saját elvesztését, másrészt valami feldolgozhatatlan, megemészthetetlen élmény behatolását az énembe. Az utóbbi folyamat magyarázatához érdemes Pintért szó szerint idézni:

A trauma eseményében olyan idegenséggel találkozunk (Freud »emberfeletti hatalmú vendégekról«, »idegen testrôl« beszél), amelyet nem tudunk feltartóztatni. A psziché kénytelen magába fogadni, és mint egy idegen testet a sajátban integrálni az élményt, amelyet kizárólag azáltal tudna feldolgozni, ha az értelmezéssel sajáttá is tudná tenni. Az integrálhatatlan élmény felszakítva addigi, viszonylagosan integrált énem burkát, anélkül vált belsôvé, hogy sajáttá is vált volna. Nem uralom, nem rendelkezem fölötte, nem érzem énemnek, pedig részem lett. (43)

Más szavakkal a psziché burkot von a traumatikus élmény köré, és idegen testként hordozza magában, mint kagyló a homokszemet. A feldolgozhatatlan trauma integrálásával egyúttal azonban a psziché maga is idegenné válik, a homokszem megváltoztatja a kagyló húsának szövetét, míg a héj változatlan marad. A kagyló egysége megbomlik. A hús elválik a héjtól, a psziché elválik a testtôl, a traumatizált egyén megszûnik egységes testi-lelki entitásnak lenni. Aldó és Klára esetében jól látható, ahogy a test tovább él, visszatérve ismerôs szokásaihoz, míg a psziché egy része együtt halt szeretteikkel, s hideg, idegen testként ernyedezik az immár csak vegetáló testben. A filmben a túlélés, a poszttraumás állapot többek között úgy jelenik meg, hogy a szereplôk lemondanak a psziché megmentésérôl, beletörődnek annak idegenségébe, és helyette a test életben tartására koncentrálnak. A pesti nôk továbbra is nôgyógyászhoz járnak, hogy fenntartsák a test alapvetô egészségi állapotát. Olgi és Aldó is minduntalan arra kéri Klárát, hogy egyen rendesen, mondván az életnek mennie kell tovább. De milyen élet ez? A túlélók valójában olyanok, mint az élóhalottak, akik azzal az idegenséggel „élnek” együtt, amely folyamatosan homokkal szennyezi, megfertôzi pszichéjük húsát, megölve bennük mindazt, ami emberi, 
ismerôs, otthonos. ${ }^{[2]}$ Visszatérve Pintér gondolatmenetéhez, a traumatizáció valami sajátnak [] Klára ás Aldó esetében nem csak szeretteik, de önmaguk egy részének is, illetve a világ iránti alapvetố bizalomnak [] az elvesztését jelenti (40-41.), amely a maguktól és a külvilágtól való elidegenedéshez, „a kül- és belvilágban való otthonosság érzésének sérüléséhez” (43) vezet. Pintér szavaival, az Akik maradtak fószereplôi „idegennek érzik magukat a külvilágban, és idegenként tekintenek saját magukra is” (41).

A traumatizáció a szubjektum idôhöz való viszonyát is radikálisan megváltoztatja, hiszen nem tud továbblépni, megragad a múltbeli élmény pillanatában, s ezáltal kiszakad a jelenból. Pintér megfogalmazásában, a „szubjektum rögzül az élményhez, [...] megreked élettörténetének ezen a pontján, és nem lesz képes időben eltávolodni tóle, ami végzetesnek bizonyul”, hiszen „[a]z átélt trauma "konzerválja " a túlélốt, ahelyett, hogy tapasztalattá válva megváltoztatná" (2014: 42-43.). Ez az objektíven kamaszkorúnak tekinthetô Klára esetében azt eredményezi, hogy [Aldó szavait idézve a lány korát firtató kérdésre, „Öt és hetven között bármennyi tud lenni” |legyszerre szeretetéhes kisgyermek, konok tizenéves, érett nô és koraérett aggastyán. ${ }^{[3]}$ A középkorú férfi esetében azt látjuk, hogy bár a konkrét, nyers élményeknek vége, Aldó a sokktól megnémulva, csendben szenved tovább. A múltbeli traumákat mindketten egy nem múló jelenként élik újra és újra: Klárának rémálmai vannak a családjáról, Aldónak már nem, viszont, ahogy Klárának egy bizalmas pillanatban elmondja, neki „ôk mindenütt ott vannak”. A férfi talán az ôt körülvevő embereknél és a fizikai valóságnál is valóságosabbnak érzékeli felesége és fiai emlék-lényeit, bár ezeket a nézô nem látja. A nyitójeleneten kívül alig azonosulunk szubjektív szemszögével. Mindenesetre mindkét fôszereplôre az jellemzô, hogy a traumatikus múltbeli élményekhez „fixálódnak” (Pintér 2014: 41), mintha a történés pillanatában „megállt volna az idô” (Herman 2003: 60). A filmben azt látjuk, hogy „a trauma történése az átélő számára és annak emlékezetében egy örökösen friss élményként van jelen, semmint tapasztalattá, tudássá, múlttá, az élettörténet láncszemévé vált volna, amellyel harmonikusan összekapcsolódhatna mindaz, ami azelôtt és azután történt” (Pintér 2014: 43). Az egységes én és a külvilággal való kapcsolat eróziója mellett a két túlélőnek az idôhöz való normál viszonya ugyancsak sérül; ebből a szempontból is élőhalottak.

A traumadiskurzus az ilyenfajta emlékezetet sérült, „traumás emlékezetnek” nevezi, amely egyúttal arra is utal, hogy az egyén az élményt nem tudja verbálisan kifejezni, az nem elbeszélhető. Pintér szerint „egy ilyen emléknek sem szóban elmesélhetô története, sem kontextusa nincsen, inkább élénk érzetek és képek formájában, nyelvi kódolás nélkül rögzül” (2014: 41). Lénárt Tamás Jean Améry A kinvallatás címú esszéjének elemzésekor szintén kiemeli, hogy a nyelvileg elbizonytalanodó környezetben a trauma „kifejezetten testi (vagyis nyelvileg nem közölhetô) élménnyé” válik (2017: 84). Hogyan tudja tehát elbeszélni és ezáltal feldolgozni Aldó és Klára az ôket ért traumákat, ha azok szóban nem kifejezhető „élénk érzetekké”, „képekké”, illetve „testi élményekké” váltak, melyek elnémították, megsüketítették óket? A jelenlegi tanulmány erre keresi a választ, és amellett érvel, hogy Aldó és Klára úgy segítik egymást a gyógyulásban, hogy pillantások, ölelések és multiszenzoriális emlékképek segítségével „beszélnek” a szavakkal el nem mondható traumákról, azaz beszéd helyett a nonverbális kommunikáció, a taktilitás és egyéb, 
szenzoriálisan tapasztalt érzetek kapnak kulcsszerepet gyászmunkájukban. Értelmezésemben az Akik maradtak filmnyelvi szempontból ezekhez a narratív értelemben megjelenô kommunikációs és traumafeldolgozási csatornákhoz hangolódik, más szóval a filmkép haptikusságára támaszkodva ábrázolja a szereplôk elbeszélhetetlen élményeit, melyet leginkább Laura U. Marks filmfenomenológiai elméletén keresztül érthetünk meg.

Marks The Skin of the Film címú klasszikus alapmúvében megkülönbözteti a távolságon alapuló, a képet perspektíván és térérzéken keresztül uraló, az embert és emberi viszonyokat egyszerre eltárgyiasító és totalizáló látásmódot, az „optikus vizualitást”, illetve a közelséget, a kapcsolati intimitást és a szenzoriális érzékelést hangsúlyozó „haptikus látásmódot”, melyet a film leggyakrabban közelik segítségével érzékeltet (2000: 162-164.). Ahogy Marks fogalmaz, „[m]íg az optikus vizualitás a képnek az ábrázolt feletti hatalmát, a haptikus vizualitás a kép materiális jelenlétét helyezi elôtérbe" (saját ford. 2000: 163). Az Akik maradtak-ban a filmkép tapintható, anyagi jellege nem átütô, ${ }^{[4]}$ azaz nem jelennek meg nagy számban olyan beállítások, amelyeket elsôsorban haptikusan érzékel a néző. Azonban a film saját, visszafogott módján igyekszik hangsúlyozni a fôszereplôk interakcióinak haptikus, multiszenzoriális voltát, így a filmnyelvet szokványosan uraló verbalitást és vizualitást egy-egy pillanatra ezektôl eltérô érzékek váltják fel. Ilyenkor az Akik maradtak a marksi értelemben maga is haptikussá, multiszenzoriálisan érzékelhetôvé válik. Az elkövetkezôkben tárgyalt filmjelenetek ezeket a pillanatokat hivatottak szemléltetni.

\section{Haptikus pillantások}

Aldó és Klára kapcsolata a nonverbális kommunikáció síkján indul és végig azon is marad. Annál a jelenetnél, mikor Klára orvosi vizsgálatra érkezik a férfi rendelôjébe, és elôször találkoznak, a nézônek az a benyomása, hogy egymás szemébe nézve, akaratlanul, szavak nélkül mesélnek egymásnak. A pillanatban kirajzolódó közös traumák mentén egymásban azonnal rokonlelkekre találnak. Habár ekkor Aladár megszólal, hiszen fel kell tennie a mechanikus, orvosi vizsgálatokon elhangzó kérdéseket, a nyitójelenet tompultsága átterjed erre a jelenetre is. A lány csendben, a holdkórosokra vagy hipnózis alatt állókra jellemzô dermedtséggel tesz eleget az orvos utasításainak; leveszi az ingét, felemeli a kezét; de a kérdésekre hosszú, dacos, néma pillantásokkal válaszol. Arra a kérdésre, hogy „Édesanyád késôn érố típus volt?”, felcsattan: „Nem volt. Csak még nem tudott hazajönni.” A film tehát a lány elsô tényleges megszólalásával megmutatja a nézônek Klára makacs tagadását, énjének veszteség okozta hasadtságát. ${ }^{[5]}$ De már az ezt megelôzô, nonverbális interakció során is meggyőződhetünk arról, hogy Klára hasonlóan elidegenült tudati állapotban van, mint a nyitójelenetben Aladár. A két „túlélôhalott” környezetétől és saját magától elidegenedve, megsüketülve és elnémulva a nonverbális kommunikáció síkjára szorul, ott találnak egymásra és egyben segítségre.

A rendelói jelenetet nem csak narratív szempontból érdemes kiemelni, hanem azért is, mert a film az ábrázolt kapcsolathoz, pillanatbeli kapcsolódáshoz igazodva azt ugyancsak nonverbálisan, a 
látás haptikusságának hangsúlyozásával mutatja be. A Kláráról kapott elsô közeli érdekesen nem az arcát, hanem blúzát kigomboló ujjait, körömágyának vörösségét, ingének textúráját, illetve az ezt követô, arcát mutató beállítás ugyancsak inkább a szeme körötti fekete karikákat, cserepes ajkait helyezi elótérbe. Ahelyett, hogy a vizualitást hangsúlyozná és totalizáló jelentéstartalmat kapcsolna hozzá, az ábrázolásmód tehát a karaktert tapintható, testi jelenlétként, a részletekből kiindulva, fokozatosan „letapogatva” ismerteti meg a nézôvel, így imitálva azt, ahogy a diegézisen belül Aladár érzékeli Klára rászegezôdô elsô pillantását. Ez a tekintet nem csak átvitt értelemben, hanem szinte szó szerint is megérinti mind az orvost, mind a nézốt.

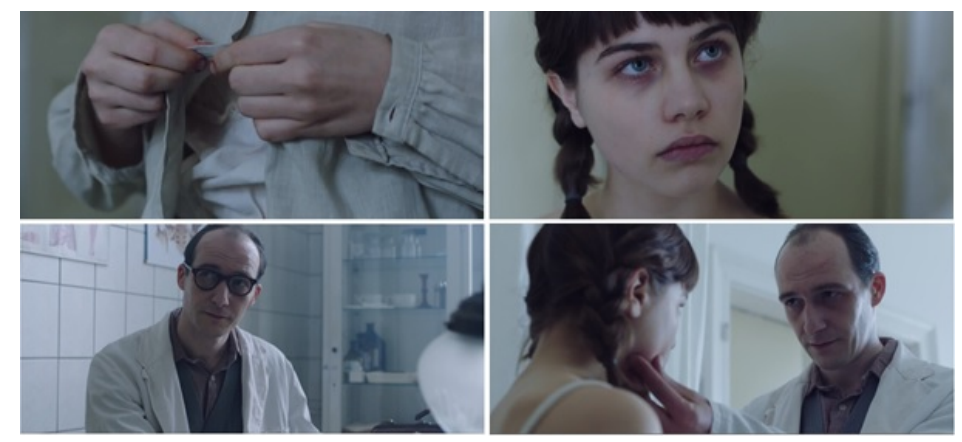

Akik maradtak (Tóth Barnabás, 2019)

Kevésbé szembeötlő, de hasonlóan haptikus jelleggel bír az a jelenetet is, amikor Aldó és Klára vendégségbe mennek a háború után két árva kislányt örökbefogadó orvoskollégához. ${ }^{[6]} \mathrm{A}$ szórakoztatásukra szóló zongoraszó felett Aldó és Klára tekintete összeér, és többet mond, mint a szavak. Pillantásaikkal egyszerre beszélnek a háború borzalmairól, az árván maradt gyerekekról és egyedül maradt szülôkrôl, az egymásban lelt vigaszról és még számtalan olyan dologról, amit a nézố nem érthet. Habár a szereplôk nonverbális interakcióját rögzítô premier plán nem kifejezetten haptikusan érzékelhetô beállítás, azáltal, hogy megmutatja a színészek arcának apró, számunkra kifürkészhetetlen rezdüléseit, a jelenetben a látás mégis diszkréten haptikussá válik, és mind a két szereplô, mind a film-nézô viszonylatban leginkább az érintés, az arcmozgások taktilis érzékelésének funkcióját tölti be. Ahogy Csomán Sándor említi kritikájában, a film egészére az jellemző, hogy „szavak nélkül is jól mesél” (2019), azonban a rendelôi vagy a vendégséget bemutató jelenetben nem csak a verbalitás, hanem a vizualitás dominanciája is megtörik, és a filmnyelv pillanatnyilag haptikus jelleget ölt. Mivel az említett taktilis természetú jelenetek fontos szerepet játszanak a poszttraumás állapot, a gyász és a gyógyulás fenomenológiájának filmes ábrázolásában, nem értek egyet azzal a kritikai állásponttal, mely szerint az Akik maradtak jobban megírt dialógusokkal és szívbemarkoló monológokkal nagyobb hatást érhetett volna el. Értelmezésemben a film pontosan azért tudja húen ábrázolni a szereplôk traumáihoz kötôdô érzeteket, illetve gyászuk és közös gyógyulásuk tapasztalatait, mert a filmnyelv nem próbálja mindenáron verbalizálni azt, amit a szereplôk sem tudnak. Helyette a filmkép haptikusságára és, ahogy arról késôbb szó lesz, multiszenzoriális voltára támaszkodik. 


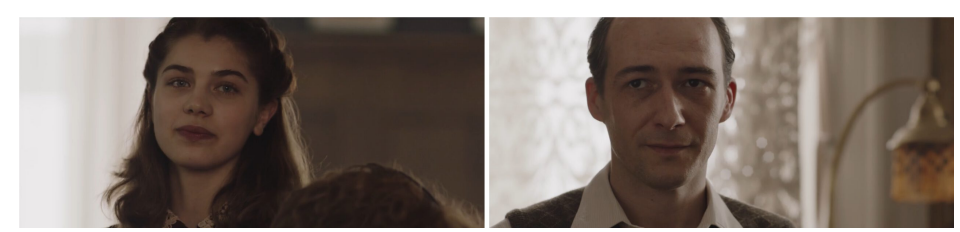

Akik maradtak (Tóth Barnabás, 2019)

\section{Haptoterápiás érintések}

Az érintés funkcióját betöltố pillantások mellett a narratív síkon megjelenô, szereplôk közti nonverbális kommunikáció másik eszköze maga az ölelés. Érdekes módon az elsô érintést az érzelmileg zárkózott Aldó kezdeményezi, mikor Klára először jár a férfi lakásán. Megsajnálja a lányt, odamegy hozzá és ráteszi kezét a vállára, majd Klára szeretetre éhesen átkarolja a derekát. Pár másodpercig a bőrükön keresztül, annak melegségével, illetve az ölelés szorításának és lazításának ritmusával kommunikálnak. Bár nehezére esik, Klára az elbúcsúzásuk pillanatában szavakkal kéri Aldót, hogy még egyszer megölelhesse. A férfi látszólag megmozdított benne valamit, amit akkor tapasztalt utoljára, mikor édesapja vagy édesanyja átölelte. Késóbb, mikor a szüleinek írt levélben beszámol az Aldónál tett látogatásról, megtudjuk, hogy Klára ugyanúgy megsajnálja Aldót. „Nem igazán tûnt úgy, mint aki bárminek képes örülni 【írja \ kicsit meg is sajnáltam.” Tehát a másik iránt érzett részvét, együttérzés szinte az elsô pillanattól fogva kölcsönös, csak úgy, mint a késôbb kialakuló, egymásban kölcsönösen megtalált vigasz. Ugyanis a másik érintése nem csak a lány lelkét éleszti fel. Mikor már együtt laknak, és Aldónál elôtörnek családja emlékei és az ezeket általában kísérô kézremegés, Klára öleléseivel vigasztalja a férfit. Tudja, hogy ha verbálisan próbálná megnyugtatni, csak rontana a helyzeten, mert Aldót valahogy minden kimondott szó elhunyt családjára emlékezteti.

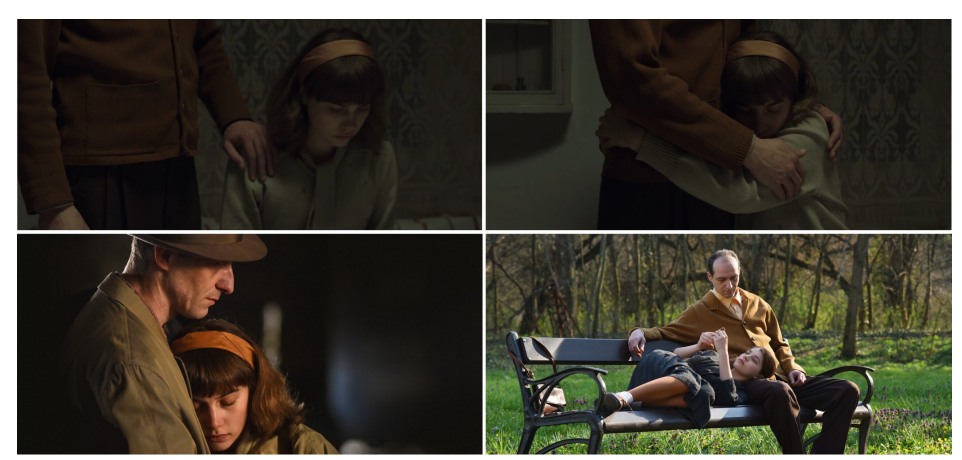

Akik maradtak (Tóth Barnabás, 2019)

Ahogy a két fốszereplố egyre több idôt tölt együtt, és kapcsolatuk egyre bensôségesebbé válik, már nem csak az otthon privát terében mernek vigaszt keresni egymás ölelésében, azonban közelségük rosszallást vált ki a helyi közösség néhány tagjában. Például abban a jelenetben, mikor fôhôseink egy parkban, egy padon ülve beszélgetnek: Klára feje a férfi ölében pihen, miközben az a haját simogatja. A jelenetet látva az arra járó kémiatanárnő, Vidákné, akinek az öntörvényú lány amúgy is a begyében van, megbotránkozik. Másnap jelenti az esetet az igazgatóasszonynál és együtt 
kifaggatják, miért volt a feje a férfi ölében, mire ô ószintén feleli, „Féltem”. De arra a kérdésre, hogy mi a viszonya Körner Aladárral, már nehezebben válaszol. A kettejük között kibontakozó intim kapcsolat nem elôször vált ki rosszallást Klára környezetében, ugyanis mikor a férfi hazakísérte a lányt az elsố személyes „találkozójuk” után, a szomszédok közül valaki látta, ahogy megölelik egymást az utcán, az információt továbbadta Olginak, aki Klárát erkölcstelenséggel vádolta. Kezdetben tehát még Olgi sem érti tizenéves nevelt lánya és a negyvenes éveiben járó orvos szoros, intim kapcsolatát és rögtön rosszra gondol. Klára közben pedig azt nem érti, mit lehet helyteleníteni egy olyan kapcsolaton, amely két megtört, magányos, rettegó embert darabjaikból újra összerak, melegséggel tölt fel és visszaállítja a magukba és a világba vetett bizalmukat. Klára ezért így kérdezi Aldót: „Miért kurva az, aki fél?”

A nézô szemszögéből vizsgálva leginkább abban a jelenetben merül fel a lehetôsége annak, hogy nem csak egy pótapa és nevelt lány kapcsolatát vagy egy különösen közeli barátságot látunk, amikor egy éjszaka fekete kabátos alakok jelennek meg a gangon. Pár percig azt hisszük, Aldót valaki besúgta, és most elviszik. A fốszereplôk remegve ölelik át egymást, egyrészt megnyugtatásként, finoman simogatva egymás arcát, karját és hátát, másrészt azzal a hévvel, amellyel egymást két utoljára látó és érintô ember búcsúzik. És miközben rettegve várják, hogy Aldót elviszik-e vagy sem, Klára végigcsókolja a férfi nyakát, aki egy pillanatra teljesen átadja magát a lány közeledésének. Ekkor azonban már halljuk, hogy az ávósok másért jöttek, és a pillanatnak vége. Habár e jelenet miatt könnyú arra a következtetésre jutni, hogy kettejük kapcsolata szerelmi viszonnyá alakult, a kibontakozó történet mégsem biztosít a nézô számára egyértelmú jeleket, melyek akár az egyik, akár a másik narratívát megerôsítenék.

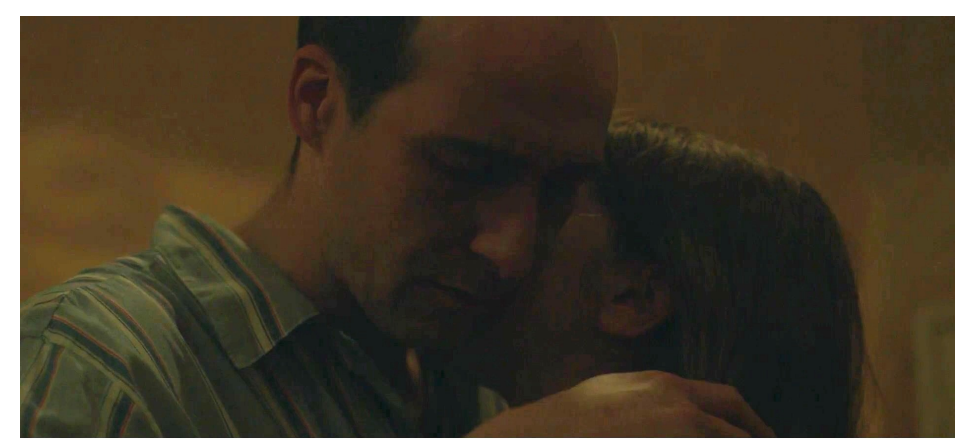

Akik maradtak (Tóth Barnabás, 2019)

Az Akik maradtak folyamatosan és tudatosan bizonytalanságban tartja a nézôt, és ez az ambiguitás a fentebb vázolt jelenetben nemhogy oldódna, hanem tetôzôdik. Hiszen Klára és Aldó kapcsolatának esetében nem érvényesek azok a társadalmi-kulturális kategóriák - apám, lányom, szerelmem, férjem vagy feleségem -, amelyeket a két fôszzereplô el tudna foglalni és biztonsággal használni. Számukra a másik mindezt és egyszerre egyiket sem jelenti. ${ }^{[7]} \mathrm{A}$ traumákban osztozó és azokat egymásnak legyốzni segítô emberek interperszonális kapcsolatait nem lehet sem a társadalmilag jóváhagyott, sem a helytelenített címkékkel ellátni. Funkciójuk, múködési nyelvük más, mint a hagyományos kapcsolatoké. Aldó és Klára esetében az számít, hogy az érintések és ölelések által megteremtenek egy olyan intim közeget, közösséget, amelyben együtt képesek 
visszaállítani „a kül- és belvilágban való otthonosság érzését” (Pintér 2014: 43). ${ }^{[8]}$ E gondolatok fényében értendô tehát Aldó válasza Klára korábban feltett kérdésére, miszerint „Nem kurva az, aki fél egyedül.” Más szóval nem lehet felcímkézni azt, aki a másikban egyszerúen a nevesíthetetlen jelenlétet és közelséget keresi, illetve érintéseit sem lehet szerelmi vagy erotikus értelemben vizsgálni. Hasonlóan a fentebb elemzett pillantásokhoz, a diegézisen belül történô érintések és ölelések funkciója a gyógyítás, vagyis az, hogy segítenek helyreállítani a két „túlélôhalott” önmagukkal és másokkal való közösségét, visszaállítani helyüket az élốk között.

A filmben a közösség felôl érkező, Aldó és Klára közelségét helytelenítô reakciók szimptomatikusak nem csak a háború utáni, de a mai, illetve nem csak a magyar, hanem az egész nyugat- és közép-európai társadalom vonatkozásában is. Társadalmainkban az érintésnek szigorú normái vannak, amelyek megszabják, hogy kik, milyen kapcsolatban, milyen testtájon és milyen erôsséggel érinthetik meg a másikat. Habár, ahogy az Akik maradtak címú filmben láthatjuk, a taktilis interakcióknak fontos szerepe van a traumatikus élmények feldolgozásában, az érintés használata az említett társadalmi szabályok miatt nem terjedt el a pszichoterápia gyakorlati alkalmazásában sem. Sốt, a páciens megérintése, átölelése legtöbb esetben kifejezetten tabu. Az érintés szükségességének figyelmen kívül hagyása azért ártalmas, mert így a terápia nem kezeli az egyént egységes testi-lelki entitásként; valójában magához a traumához hasonlóan megbontja a túlélố pszichéjének, lelkének és korporalitásának egységét.

Ez ellen kíván megoldást nyújtani a haptonómia, egy alternatív pszichoterápiás módszer, melyet a holland származású Frans Veldman alkotott meg az ötvenes években. Veldman a zsidóüldözések idején, a koncentrációs táborokban figyelte meg, hogy milyen nagy jelentôsége van a túlélésben az affektív kontaktusnak. A háború után Hollandiába visszatérve megfigyeléseit mozgásterapeutaként gyakorlatba ültette. Tapasztalatai megerôsítették feltevéseit, miszerint a páciens bizonyos testpontokon való megérintése (például hát, kar, nyak) terápiás hatással bír. Veldman holisztikus, emberközpontú megközelítése a fizioterápiában egybevágott az akkoriban mutatkozó orvostudományi, pszichológiai és filozófiai fejleményekkel. E területeken egyre több tudós kritizálta azt a felvilágosodás óta állandósult felfogást, miszerint a test és a lélek az ember két elkülöníthetô részét alkotja. Egyikük a francia filozófus Maurice Merleau-Ponty volt, aki amellett érvelt, hogy a test és a lélek elválaszthatatlan egységet alkot, ezért a testi érzékelések közvetlen, fenomenológiai megfigyelése ugyanolyan fontos az egyén pszichéjének vizsgálatakor és patologikus tüneteinek kezelésekor, mint a természettudományok által használt kísérletek és empirikus bizonyítékok. Merleau-Ponty elmélete többek között a híres fiziológus, pszichológus, antropológus és filozófus F.J.J. Buytendijknek, illetve Dr. J.J.G. Pricknek köszönhetôen terjedt el a holland akadémiai körökben. Egyetemi előadásaikon mindketten a test és a lélek egységérôl, a korporalitás, valamint a taktilis érzékelés jelentôségeirôl beszéltek. A nijmegeni egyetem lett a központja annak az új, általuk meghonosított antropológiaalapú orvoslásnak, mely a testi érzeteket egységben kezelte az ember intellektuális és pszichológiai képességeivel. Buytendijk és Prick Nijmegenben tartott, test-tudatosságról, tapintásérzékelésrôl, gyengédségrôl és társas kapcsolatokról szóló előadásain Frans Veldman visszacsatolást talált saját megfigyeléseihez. A 
következô években Veldman tovább mélyítette tudását a filozófia, pszichológia és antropológia területein és a tanulmányai során megismert elméleteket összekapcsolta sajátjaival, végeredményül pedig kidolgozta a haptonómia tudományát és módszerét. [9]

Az MPPPOT (Magyar Pre- és Perinatális Pszichológiai és Orvostudományi Társaság) oldalán olvasható összegzés szerint a haptonómia „a nonverbális kommunikációra épít, integrálja a különböző érzékszervekkel létesített kontaktusok széles skáláját.” Ebból kifolyólag a haptonómia különleges szerepet tulajdonít az érintésnek, ${ }^{[10]}$ melyről, ahogy arra fentebb utaltam, a nyugati kultúrákban elsôsorban erotikus és agresszív viselkedésre asszociálunk. Ezzel szemben a haptonómiás érintés „gyengéd, szemérmes, egyenes, »meghallgató«, ezáltal terápiás, gyógyító hatása van" (https://www.mpppot.hu/perinatalis-tudomanyok/perinatalis-terapiak/haptonomia). Weiszburg Anna haptonómiát bemutató tanulmányát olvasva további részleteket tudhatunk meg az elmélet alkalmazásáról, azaz a haptoterápiáról, mely során a páciens és a terapeuta a beszéden túl a páciens meghosszabbodását biztosító érintés-kontaktus révén létesít kapcsolatot egymással, melyet a haptonómia átnyúlásnak, átfolyásnak (franciául prolongement) nevez (2011: 31-33.). Mikor a terapeuta megérinti a páciens testének az adott helyzetben jelentős pontját, „a páciens teste »meghosszabbodik, átnyúlik « a terapeuta kezébe, karjába, testébe”, és ez „a másikba való átfolyás az érzetek és reakciók alapvetô módosulásához vezet, amelyre egy egész terápiás program építhetô” (Weiszburg 2011: 32). Az idézett leírások tehát egyetértenek abban, hogy a haptoterápia segíti a traumatizált egyén visszatalálását a világ iránti alapvetô bizalomhoz, ahhoz „az affektív alapbiztonsághoz, ami utat nyit az autonóm és bizalmat árasztó világ lehetôségei elôtt" (MPPPOT). Mindezek tekintetében Frans Veldman tevékenységét hiánypótlónak tekinthetjük a traumafeldolgozás terén, azonban a haptonómia a nyugati pszichoterápiás hagyományokat uraló „érintési tabu” miatt a legtöbb európai országban nem tudott gyökeret verni.

Egy másik terápiás módszert, mely nem kifejezetten az érintésre épít, de következetesen használja azt, John W. James az 1970-es években dolgozta ki, miután kisfia elvesztése után képtelen volt érzelmileg felépülni. Az úgynevezett Gyász- és veszteségfeldolgozás Módszert önerôból, csoportterápiás keretben alkotta meg, ahol a gyásszal küzdô egyének egymásra támaszkodva gyógyulnak. Varga Hedvig, Sarungi Emôke és Csabai Márta leírásában:
A Gyász-és veszteségfeldolgozás Módszer ${ }^{T M}{ }$ (The Grief Recovery Program $\left.{ }^{\circledR}\right)$ egy olyan felnôtteknek szóló, strukturális gyakorlatokra épülő, cselekvés-központú, alapvetően önsegítô veszteségfeldolgozási technika, melynek elsajátítása során az egyén az önsegítés lehetôségének pozitív élménye mellett megtapasztalhatja a csoport támogató erejét is. A csoportban való részvétel hatására a legtöbb gyászoló átéli a „nem vagyok egyedül”, „másoknak is hasonló problémái vannak” felszabadító élményét, mely már az elsô néhány csoportfoglalkozás során megkönnyebbüléshez vezethet. (2015: 369-370.)

A csoporttagok közötti, minden esetben konszenzuális érintésnek, ölelésnek ugyanez a célja. A fent idézett szerzôk összesen négy elkülöníthetô funkciót tulajdonítanak a terápiás alkalmakon használt ölelésnek: 1) támasz, amely kifejezi, hogy a gyászoló nincs egyedül a megosztott érzelmekkel; 2) az 
„erősnek kell lenni” mítoszának elengedése, a gyásszal járó érzések elfogadása, átélése; 3) az egyénnek a társak által való elfogadása, minden megosztott élményével együtt; és 4) taktilis kapcsolat létesítésével az adott jelen pillanat élményének megerôsítése és ezáltal kilépés az érzelmi izolációból (2015: 375). Összefoglalva az érintés szerepe a traumafeldolgozásban egyfajta földelés, stabilizáció, a disszociatív állapotban lévő psziché visszarántása a testbe, az elvesztett biztonságérzet visszaállítása. Ezáltal a másik ölelése segít az én környezetétôl és saját magától való elidegenedés visszafordításában. Hatására a traumatizált szubjektum újra megtalálhatja az önmagával alkotott közösséget, a saját magával érzett otthonosságot, a testi-lelki egységet. Ahogyan Veldman és James módszerei is tanúsítják, az interperszonális, illetve közösségi intimitásnak igen nagy szerepe van a gyászmunkában és a gyógyulásban.

Az Akik maradtak a fent bemutatott alternatív pszichoterápiás módszerek képviselte szemléletet közvetíti, és cselekménye kifejezetten optimista a Holokauszt okozta traumák feldolgozhatósága kapcsán. Ez megmagyarázza, hogy a filmrôl alkotott általános kritikai konszenzus konklúziója szerint az Akik maradtak a továbblépésrôl és feldolgozásról szól, és végsô soron azt tárja elénk, hogy megfelelô társsal és segítséggel az idô sok sebet képes orvosolni. ${ }^{[11]}$ Ezzel az állásponttal egyetértésben úgy vélem, hogy fôhoosseink részben az érintéseknek és öleléseknek köszönhetôen találnak vissza az élốk közé. Az, hogy ezek milyen további jelentéstartalommal tölthetôk fel, a nézók értelmezésétól függ, de a traumatizáció, a gyász és a gyógyulás fenomenológiájának filmes ábrázolása szempontjából nem lényegesek. A film végsô soron azt az üzenetet közvetíti, hogy a haptikus interakcióknak „meghallgató”, gyógyító, terápiás hatása van, így a hozzájuk kapcsolható baráti, apa-lány vagy romantikus viszonyt láttató jelentéstartalmak másodlagosak. Az érintések és ölelések haptoterápiás jellegének nyomatékosítása egy-egy jelenet erejéig pedig magát a filmnyelvet is haptikussá teszi.

Azok a jelenetek, melyekben a szereplôk gyászmegosztás vagy vigasztalás céljából megérintik vagy megölelik egymást, így az interakció során létrejön az átfolyás, átnyúlás, mely a haptonómia szerint gyógyító hatással bír a traumatizált egyénre, kifejezetten sötét tónusúak. Ide tartoznak a fentebb említett, öleléseket ábrázoló jelenetek, köztük az is, mikor Aldó és Klára az ávósok betörésétôl rettegve átölelik egymást, és a lány finoman végigcsókolja a férfi nyakát. Pillanatnyilag összefonódó alakjuk alig kivehetô, szinte beleolvad a sötét szoba alkotta háttérbe, így a nézô szeme elôtt nem rajzolódik ki világosan, pontosan mi is történik kettejük között. A filmnyelv tehát igazodik a narratív síkon megjelenô intim, haptikusan megélt interakcióhoz; az a kép sötétsége miatt a nézô számára is elsôsorban haptikusan érzékelhetô, ami megakadályozza, hogy azonnal totalizáló jelentéstartalmat kapcsoljanak hozzá.

Hasonló jelleggel bírnak azok a jelenetek, mikor Klára és Aldó egymás mellett alszik, és legtöbbször felsô kameraállásból látjuk, ahogy alakjuk belesimul az ôket körülvevô ágynemúbe. A textilek tapinthatósága kiterjed a karakterekre, a függönyök mintája pedig árnyakként tovább folytatódik a szereplôket keretezô falon is; az egész kompozíció elsôsorban tapinthatóként jelenik meg, igazodva a szereplôk viszonyának intimitásához. Egy hasonló jelenet során Klárának rémálma van, Aldó felkel, a lámpához kászálódik, sötétben tapogatózik, ahogyan a film is. Hiszen 
egy ponton a férfi alakja eltakarja a kamerát, csak pizsamájának körvonalazhatatlan foltját tudjuk kivenni. A filmkép ekkor kifejezetten a Marks által leírt haptikus látásmódba vált, mely felerôsíti az elkövetkezô vigasztaló ölelés ugyancsak taktilis érzékelését.

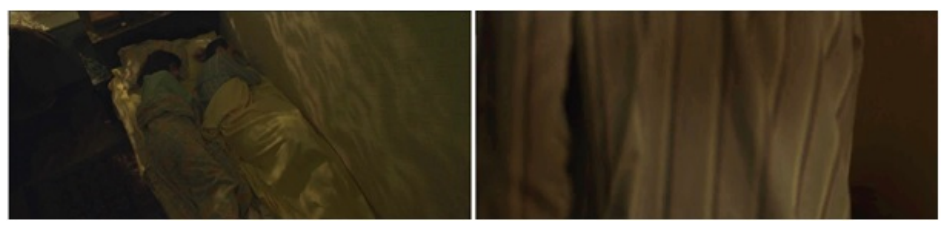

Akik maradtak (Tóth Barnabás, 2019)

\section{Multiszenzoriális emlékképek}

Habár érzelmeit igyekszik elfojtani, Aldónak is szüksége van a vigasztalásra, a gyógyulásra, és egy ponton az ölelések már nem elegendôk; úgy érzi többet kell tennie, hogy megoszthassa fájdalmát a lánnyal. Azt úgy teszi, hogy egy nap, mikor már együtt élnek, levélben arra kéri a Klárát, nézze meg családi fotóalbumait, amíg ô nincs odahaza. Röviden hagyja a képeket szavak nélkül beszélni. Klára a fotókról visszaköszönô családi idill és az annak véget vetố elképzelt kegyetlenségek hatása alatt Aldó napáztatta szőnyegére hajtja a fejét, az ablakra emeli könnyes szemeit, és ekkor saját lakásuk ablaka, majd egy derûs családi délután történései sejlenek fel elôtte. Emlékképei máskor is elôjönnek, főleg egy-egy gondoskodó gesztus vagy a régi életére emlékeztető érzéki impulzus (kép, hang, íz, illat) hatására. Így például mikor Aldó fürdôt készít neki, Klára a meleg vízben ülve azt vizionálja, hogy együtt pancsol kishúgával, akit látott meghalni a lágerben. De a képek kifejezetten Aldó lényéhez is szorosan kötôdnek. A lány nem hiába talál rokonlélekre az orvos személyében, hisz annak foglalkozása, kora, alkata, vonásai, gesztusai, szokásai, de még illata is az apjára emlékeztetik. ${ }^{[12]}$ És habár azt gondolnánk, hogy a traumatizált kamaszlány tudatába élénken betörô emlékképek csak súlyosbítják az elidegenedés állapotát, víziói valójában segítenek a veszteség feldolgozásában.

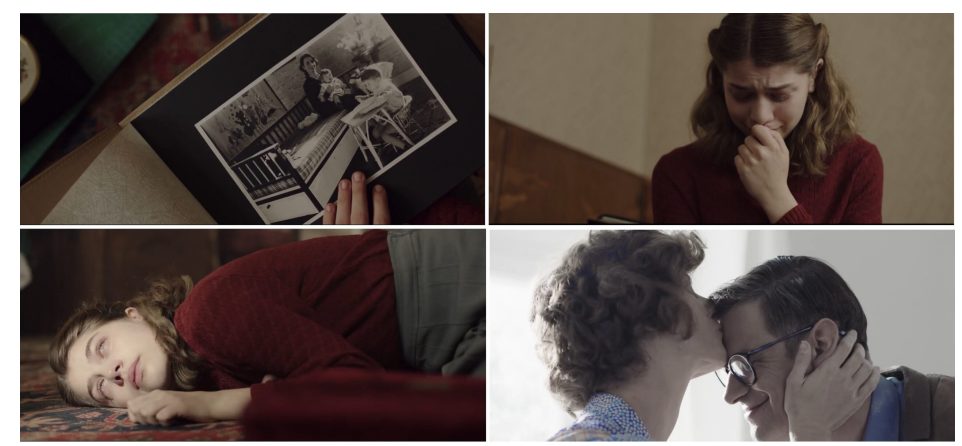

Akik maradtak (Tóth Barnabás, 2019)

A filmnyelv igyekszik igazodni Klára emlékképeinek multiszenzoriális jellegéhez, így az ezeket bemutató jelenetekben több érzékkel érzékelhetôvé válik. A fent említett fürdôszobai jelenetben a meleg víz, mint Aldó gondoskodó ölelésének kiterjesztése, előhozza Klára fürdôs emlékeit. A film tónusa ezzel egy idôben kivilágosodik, így mintha az emlékkép élesebb, kitapinthatóbb, 
valóságosabb lenne a jelennél. A víz csobogó hangja pedig tovább erôsíti a jelenet multiszenzoriális természetét; már-már olyan érzésünk lehet, mintha a filmkép vízzé válva saját bôrünket is simogatná. A nézó érzékeinek bevonása abban a jelenetben ugyancsak kiemelkedô, amikor a borotválkozó Aldót nézve Klára a tükörben édesapját vizionálja. A nézô a lány optikai perspektívájával azonosul, így mikor az apa habos borotvapamaccsal közelít a kamera felé, olyan, mintha a mi orrunkat készülne összekenni, ezáltal összekötve saját taktilis érzékelésünket Kláráéval. Ugyanez történik abban a jelenetben is, mikor a lázas lányt Olgi ápolja, de ô közben édesanyját látja. Megint Klára szubjektív nézôpontjával azonosulunk, így a hidegvizes ruha érintése egyszerre éri a szereplố és közvetetten a nézô homlokát. Látszólag a traumától szenvedô lány emlékképei tehát a legtaktilisabbak. Ez nem meglepó, hiszen, ahogy Marks fogalmaz, a haptikus filmkép „néha személyes és családi emlékek felszínre hozatalát igényli, ami egy olyan üres teret teremt, ahol a történelem bizonytalan” (5). Az ilyen pillanatokban „a történet megakad, elnyeli az üresség, amely narratív szempontból híg, de érzelmileg sûrú: a gyászmunka terméke ez, kutatás azok után, akik elmentek és nem lehet ôket visszahívni semmilyen múvészi eszközzel” (5), legfeljebb az emlékek multiszenzoriális ábrázolásával, ahogy azt az Akik maradtak-ban láthatjuk.

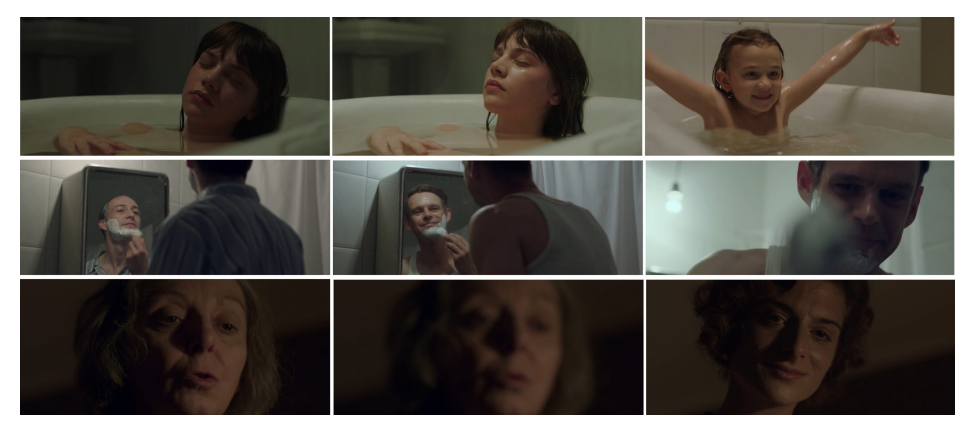

Akik maradtak (Tóth Barnabás, 2019)

\section{Haptikus színészi játék}

A film nem kifejezetten meghatározó, de kitapintható haptikus jellege nem utolsó sorban a kifinomult színészi munkának köszönhetô. E tekintetben, és egyszerre lezárásképpen, szeretném kiemelni Hajduk Károly alakítását, aki némaságával többet mond a Holokauszt-túléló szubjektív tapasztalatairól, mint a Klárát alakító Szôke Abigél összes megszólalása együttvéve. Hajduk testbeszédével, kezének remegésével, arcának rezdüléseivel tökéletesen testesíti meg az elfojtás, a magány, a traumatizált egyén önmagától és környezetétôl való elidegenedés tapasztalatait. Habár a két színészi alakítás közötti különbség megmagyarázható azzal, hogy a szereplőik máshogyan dolgozzák fel a veszteségeket [ Klára tüskés, cserfes, excentrikus kamaszlányként intenzíven, legtöbbször verbálisan mutatja ki érzelmeit, míg Aldó magába zárkózik [, Szóke Abigél színészi játéka a szereplôtôl függetlenül is inkább a verbális kifejezési formákat részesíti elônyben, és ezzel kissé „ellentmond” a Hajduk alakítása által megerôsített haptikusságra támaszkodó filmnyelvnek, amely a trauma elbeszélhetetlenségét hivatott ábrázolni. 


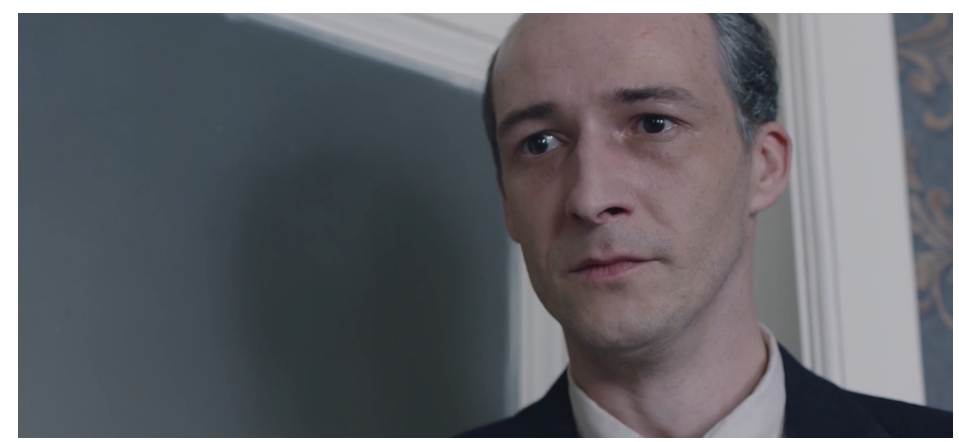

Akik maradtak (Tóth Barnabás, 2019)

Egyúttal a film arról sem feledkezik meg, hogy a trauma bár enyhül, teljesen soha nem múlik el, s ezt is leginkább Hajduk tudja kifejezni. A film zárójelenetében a fố cselekmény után három évvel járunk, Olgi születésnapi összejövetelén, ahova Klára már Pepével, míg Aldó saját társával, Erzsivel érkezik. A férfit a szokatlan közösségi, már-már családinak tetszô idill megtöri, visszavonul a fürdôszobába. Klára megérzi, hogy valami nincs rendben, így bekopog, de a megszokott vigasztaló ölelés elmarad, a lány annyit mond, hogy szeretne kezet mosni. A kettejük között elhangzó normalitást hangsúlyozó párbeszéd után a lány bemegy a fürdôszobába, és Aldó kint marad egyedül, az ajtófélfának támaszkodva. Egy pillanatig kitörni látszik belôle a fájdalom, remeg, lélegzése felgyorsul, szeme mintha olyasvalakit keresne, aki nincs jelen. Majd vonásai rendezôdnek, szája alig észrevehetôen felfelé ível, mosolyt mímel, hosszan pislant, sóhajt egyet, nyel kettôt, majd visszatér a társaságba. Parányi gesztusaival Hajduk húen fejezi ki azt, hogy bár a trauma féken tartható, de soha nem tûnik el, idegen testként örökké az én része marad. Azt, hogy a túlélô egyszerre él és halott. A gyógyír az, ami tünékeny, mint egy pillantás vagy egy röpke érintés: a film végsố soron errôl szól, és ezt az elsôsorban testi élményt testesíti meg. Az Akik maradtak tehát nem csak optimista üzeneteket közvetít a Holokauszt-túlélôk traumáinak feldolgozásáról. Tárgyát úgy dolgozza fel, hogy a gyógyulás mellett, Hajduk haptikus színészi játékénak köszönhetôen érezteti a bekötözött, de továbbra is lüktetô sebeket. Mint Aldó, a film is megremeg, felnyög, ejt pár könnycseppet, majd nagyot sóhajt és elhallgat. Hallgatásával pedig többet mond, mint egy szívbemarkoló záró dialógus vagy monológ.

\section{Jegyzetek}

1. Evési szokása valószínúleg hozzájárul ahhoz, hogy tizenhat évesen még nem menstruál, ezzel a problémával keresik fel Olgival az orvost a film elején.

2. A Holokauszt-túlélő élôhalottként való ábrázolására az amerikai moziban például az 1964-es $A$ zálogos ( The Pawnbroker, Sidney Lumet) címú filmben találhatunk precedenst, ahol az idősödô zálogházas, Aldóhoz és Klárához hasonlóan, érzelmeit elfojtva vegetál. Kárpáti Ildikó elemzésében részletesen jellemzi a karaktert: „rutinok által múködtetett egyhangú mindennapjaiban a legtöbb erôfeszítést arra áldozza, hogy a környezetében élook és társaságát keresók felé semmilyen érzelmet, a kötődés leghalványabb jelét se mutassa. A zálogosról megtudjuk, hogy Európában egyetemi professzor volt, Auschwitzban az egész családját elveszítette, és azóta az amerikai nagyváros legrosszabb negyedében múködtetett zálogházban magát élve eltemetve él. A múlt folyamatosan kísérti, de azzal sem szembenézni nem képes, sem feldolgozni nem tudja” (2014: 127). 
3. Az 1945-ben játszódó, ugyancsak koncentrációs táborokból szabadult emberek gyógyulását bemutató Hajnali láz (Gárdos Péter, 2015) nôi főszereplôjének, Lilinek a korát ugyancsak nehéz (szubjektíven) meghatározni. Barátnője, Judit fenyegetésként tekint Miklós, a férfi főszereplő Lilihez való közeledésére, és így próbál a segítségül hívott rabbinál érvelni szerelmi viszonyuk megakadályozása mellett: „Lili még kislány. Tizenkilenc éves.” Mire a rabbi így felel: „Manapság egy tizenkilenc éves már érett nô. Amiken maguk keresztül mentek...”. Habár az Akik maradtak Klárája csak tizenhat éves, a rabbi által megfogalmazott, traumák okozta koraérettség rá nem kevésbé érvényes.

4. Ha bátrabb lenne a haptikus vizualitás alkalmazásában, valószínúleg kevésbé lenne fogyasztható a nagyközönség számára.

5. A fentebb említett Hajnali lázban Lili hasonlóan tagadja szülei elvesztését, habár ott késóbb kiderül, hogy az édesanyja még él. Mikor Judit csatlakozik a svédországi eksjöi kórházban ápolt Lilihez és a harmadik barátnőjükhöz, a találkozás eksztatikus örömét Lili csüggedt, kissé összefüggéstelen, töredezett mondatai váltják fel: „Anyukáról nincs hír. Apukáról sincs... nem szeretek erre gondolni... Ti nem féltek?” Habár barátnôi nem hajlandóak válaszolni, a bekövetkezô csend a legrosszabbat sejteti.

6. Itt azt is fontos megjegyezni, hogy az egyik nevelt lány „nem beszél”, így tekinthetjük ôt Aldó, az átvitt értelemben vett „néma” hasonmásának, akit a traumák szó szerint megnémítottak.

7. Judit karaktere a Hajnali lázban például azért tekint fenyegetésként a Miklós és Lili között kibontakozó szerelmi viszonyra, mert az azt az intim közösséget látszik felbontani, amelyben a három barátnô egymást támogatva élte túl a koncentrációs tábor borzadalmait, és amely a szabadulást követôen segítette újra megtalálni önmagukat. A kis közösséget alkotó egyénekre tehát ugyanúgy egyszerre érvényes és érvénytelen az összes társadalmilag alkalmazható kategória, mint az Akik maradtak-ban. Judit ekképpen fenyegeti Miklóst: „Hagyd békén a kishúgomat... átvitt értelemben mondom... húgomat, barátnômet, a lányomat."

8. Fontos ezt is megjegyezni, hogy Klára nem csak Aldóban találja meg a pótszülôt: a nagynénje ölébe ugyanúgy odafekszik, mikor vigaszra van szüksége, és mikor Olgi ápolja, mikor ô lázasan az ágyat nyomja, édesanyját látja benne.

9. A fenti összefoglaló Frans Veldman szerepérôl a haptonómia kialakulásában Dolly Verhoeven In Touch: $A$ History of the Haptotherapy Profession in the Netherlands (2013: 13-22) címú könyve alapján készült, a fordítás a sajátom.

10. A haptonómia szó a klasszikus görög hapsis (érintés, érzékelés, tapintás) és nomos (törvény, szabály, norma) szavak összetételéból származik. A haptonómia összetétel tehát átvitt értelemben azt jelenti, hogy „tapintással kapcsolatot teremtek, hogy valakit egészségessé tegyek, hogy megerôsítsem ôt létezésében” (https://www.mpppot.hu/perinatalis-tudomanyok/perinatalis-terapiak/haptonomia).

11. Lásd Csomán Sándor és Zakariás Eszter kritikáit.

12. Ahogyan egyik szüleinek szóló levelében írja, „Papus, egyébként képzeld, Aldónak olyasmi illata van, mint Neked. De lehet, hogy csak a pizsamájának. Ezt még kiderítem.”

\section{Irodalomjegyzék}

- Csomán, Sándor: A feldolgozás lélektana - Akik maradtak. Kritika. Apertúra Magazin, 2019.09.28. URL: https://magazin.apertura.hu/film/a-feldolgozas-lelektana-akik-maradtakkritika/10094/.

- Haptonómia. URL: https://www.mpppot.hu/perinatalis-tudomanyok/perinatalisterapiak/haptonomia. 
- Herman, Judith (2003): Trauma és gyógyulás. Budapest, Háttér, Kávé, NANE Egyesület.

• Kárpáti, Ildikó (2014): „Ilyenek voltunk” - A zsidó identitástudat ábrázolásának kultúraszociológiai olvasata az amerikai játékfilmekben. PhD Disszertáció. Budapest, Országos Rabbiképzô - Zsidó Egyetem, Zsidó Vallástudományi Doktori Iskola.

- Lénárt, Tamás (2017): Traumatestek: A trauma és a halál elbeszélhetôsége: Jean Améry és Nádas Péter. Alföld, 68.7. 83-90.

- Marks, U. Laura (2000): The Skin of the Film. Durham, London, Duke University Press.

- Pintér, Judit Nóra (2014): A nem múló jelen: Trauma és nosztalgia. Budapest, L’Harmattan.

- Varga, Hedvig, Sarungi Emóke és Csabai Márta (2015): A gyász és az érzelmi veszteségek feldolgozásának új lehetôsége. In Gyász, krízis, trauma és a megküzdés lélektana. Szerk. Kiss Enikő Csilla, Sz. Makó Hajnalka. Pécs, Pro Pannonia, 368-381.

- Verhoeven, Dolly (2013): In Touch: A History of the Haptotherapy Profession in the Netherlands. [Werken met gevoel. Geschiedenis van het beroep haptotherapeut in Nederland]. Hilversum, The Netherlands, magánkiadás.

- Weiszburg, Anna (2011): Haptonómia - a gyógyító érintố kontaktus alkalmazása a palliatív ellátásban. Kharón Thanatológiai Szemle, 1.4. 29-38.

- Zakariás, Eszter: Nehezebb, mint menni - Akik Maradtak. Apertúra Magazin, 2021.03.30. URL: https://magazin.apertura.hu/film/nehezebb-mint-menni-\%e2\%80\%92-akik-maradtak/10634/.

\section{Filmográfia}

- Akik maradtak (Tóth Barnabás, 2019)

- Hajnali láz (Gárdos Péter, 2015)

- A zálogos (The Pawnbroker, Sidney Lumet, 1964) 
(c) Apertúra, 2021. nyár | www.apertura.hu

webcím: https://www.apertura.hu/2021/nyar/laszlo-tulelohalottak-a-poszttraumas-allapot-a-

gyasz-es-a-gyogyulas-fenomenologiaja-az-akik-maradtak-2019-cimu-filmben/

https://doi.org/10.31176/apertura.2021.16.4.3

(Q) opertúro 